\title{
Influence of Propagation Technique on Successful Graft and Growth Performance of Pepper Plants
}

\author{
Lakshmana*, Mahesh Math and U. S. Sachin \\ Agricultural and Horticultural Research Station, Ullal, \\ University of Agricultural and Horticultural Sciences, Shivamogga, India \\ *Corresponding author
}

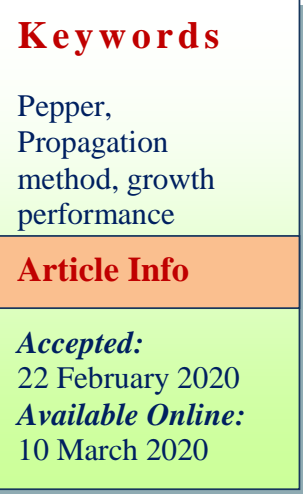

\section{A B S T R A C T}

The propagation of rooted pepper plants and grafted pepper plants were produced by using orthotropic vine and plagiotropic branch of Paniyur-1 pepper plants, during the period 2015 to 2018 at Agricultural and Horticultural Research Station, Ullal. The one batch of cuttings of orthotropic pepper vine and plagiotropic branches were rooted in 4'X6' poly bags and another batch of cuttings of orthotropic pepper vine and plagiotropic branches were grafted over on the Pepper colubrinum root stock for the study under 50 per cent shade house condition. The Propagation study showed that successful 64 per cent of rooted pepper plants and 86 per cent of grafted pepper plants were produced in rooted and grafted pepper cutting of orthotropic vine. The Propagation study of plagiotropic branch of paniyur-1 pepper showed that, successful 35 per cent of rooted pepper plants and 95 per cent of grafted pepper plants were produced. The per cent successful was observed more in grafting method compared to rooting method of propagation. The growth performance and development of rooted plants of orthotropic vine cuttings and plagiotropic branches showed significantly higher compared to grafted plants after the propagation.

\section{Introduction}

Pepper (Pepper nigrum) is one of important commercial spice of India which is a major producer, consumer and exporter of black pepper in the world. It is a crop of tropical and sub-tropical regions and requires tropical and sub-tropical climate condition. Black pepper is native to south India and is extensively cultivated there and elsewhere on tropical regions and is a flowering vine in the family Piperaceae, cultivated for its fruits which are usually dried and used as a spice and seasoning. It has been found in vast altitudinal regions and showed great adaptability to a wide range of environmental conditions (Howard, 1973). Dried ground pepper has been used since antiquity for both its flavor and has a medicine. Black pepper is reputed in the ethno medicine of many 
countries for its multi - dimensional medicinal properties (Scott et al., 2008). The pepper is one of the most common spice on European cuisine and its descendants. The fruit known as a pepper corn when dried, dark red when fully mature and contains single seed.

Bush pepper is a miniature pepper plant in the shape of a bush grown as a potted plant with decorative and economic value, raised from lateral branches (Plagiotropic branch) of yielding vines using a rooting hormone. Black pepper can propagated by seeds, cutting, layering, and grafting. Seed propagation often results in genetic variation while other methods of black pepper propagation are slow and time consuming (Atal and Banga, 1962). So, there is a need to introduce efficient methods for faster propagation of black pepper. In different countries of world viz. India, Sri Lanka black pepper plants are multiplied rapidly in order to get more seedling in short duration and for quality planting material (Sivaraman, 1987).

Considering this in the view, the present investigation on performance of rooted and grafted pepper from orthotropic and plagiotropic branches of paniyur -1 tried on experimental as well as commercial scale production. The batches of experiments were carried out in 50 per cent shade net house and propagated pepper plants are planted in cashew orchard of Agricultural \& Horticultural Research Station Ullal with recommended dose of fertilizer.

\section{Materials and Methods}

The rooted and grafted pepper plants were raised by using orthotropic and plagiotropic branches of pepper variety Paniyur-1 for 3 years. The 10 years old of 10 Paniyur- 1 plants were selected for the study. The orthotropic branches of 100 cutting were planted in 4'X6'
PF bags and kept in 50per cent shade house for rooting and sprouting. Another set of 100 cutting were grafted above on the Pepper colubrium, as root stock plant and kept in the shade house for rooting and sprouting. All the leaves of orthotropic cuttings were removed and dipped in 0.2 per cent copper oxychloride solution for 20-30 minutes before planting.

In the some way plagiotropic branches of 100 cutting were planted in 4'X6'. PE bags and kept in 50 per cent shade house for rooting and sprouting. Another set of 100 cuttings of plagiotropic branches were grafted above on the Pepper colubrium, as root stock plant and kept in shade house for sprouting. All the leaves of plagiotropic branches cuttings were removed except flag leaf and dipped in 0.2 per cent copper oxychloride solution for 2030 minutes before planting.

For commercial multiplication each 3000 plants of rooted and grafted plants were produced. The observations like, No. of cutting planted, No. of cutting grafted, per cent rootting and grafting success and per cent saleable plants are produced were noted.

Field experiment was conducted for two years at Agricultural and Horticultural Research Station Ullal, University of Agricultural and Horticultural Sciences, Shivamogga; Karnataka from 2012 to 2015 to study the performance of rooted and grafted pepper plants. The Research Station, located in a cashew growing belt, has mainly typical laterite soils of the West Coast with patches of red sandy loam.

Experiment was laid out in Randomized block design with ten replications. The observation like yield $(\mathrm{kg})$, plant height $(\mathrm{cm})$, stem girth (cm), canopy spread (ft), leaf area (cmsq) and vegetative shoot were noted from 2012 to2015. The experimental data of each 
observation on cashew plants were subjected to ANOVA separately in RCBD. The level of significance used in " $F$ " and " $\mathrm{t}$ " test was $\mathrm{P}=0.05$. Critical difference value were calculated wherever ' $\mathrm{F}$ ' tests were significant (Panse and Sukhatme, 1985).

\section{Results and Discussion}

The growth performance of propagated plants of orthotropic and plagiotropic branch of pepper studied at Agricultural and Horticultural Research Station, Ullal showed in the Table-1 \& 2. The results revealed that, rooted pepper plants maintained more or less uneven plant height, uniform canopy spread and more No. of branches were recorded compared to grafted bush pepper plants and showed significant difference.

The uniform yield and plant height is noted in grafted bush plants. But more yield noted in rooted pepper plants of plagiotropic branches.The more yield in rooted bush pepper plants may be due to more number of fruiting branches in the plants. The uniform plant height and yield in grafted bush plants may be due to effect of grafting method on the yield and development of fruiting branches. The Table -5 showed that, in both orthotropic and plagiotropic branches of cutting rooted and sprouted in poly bags showed less success compared grafted method both in large scale and experimental level. This may be due to more effective union of pepper scion on root stock, hence the good successful.

The growth performances of plants produced from orthotropic branches showed in Table 3 and 4. Results revealed that, plant growth was slow in grafted plants and significantly faster growth observed in rooted plants. The canopy spread and vegetative branch are more in rooted pepper compared to grafted pepper. The numbers of branches were also varied in different treatments. The result of the present study corroborated with the findings of the Khandekar et al., (2004) who also found superior vine length, nodes per vine and number of roots per vine from soil mound method.

Table.1 The yield and plant growth performance of rooted bush pepper plants

\begin{tabular}{|c|c|c|c|c|c|c|c|}
\hline Treatments & $\begin{array}{c}\text { Plant height } \\
(\mathbf{c m})\end{array}$ & $\begin{array}{c}\text { Plant girth } \\
(\mathbf{c m})\end{array}$ & $\begin{array}{c}\text { Branch } \\
\text { girth } \\
(\mathbf{c m})\end{array}$ & $\begin{array}{c}\text { Leaf } \\
\text { area } \\
\left(\mathbf{c m}^{\mathbf{2}}\right)\end{array}$ & $\begin{array}{c}\text { Canopy } \\
(\mathbf{f t})\end{array}$ & $\begin{array}{c}\text { No. of } \\
\text { vegetative } \\
\text { branch(No) }\end{array}$ & $\begin{array}{c}\text { Yield } \\
\text { intercrops } \\
\text { (gms) }\end{array}$ \\
\hline $\mathbf{1}$ & 46.00 & 2.00 & 2.00 & 188.67 & 4.17 & 15 & 390 \\
\hline $\mathbf{2}$ & 40.67 & 1.96 & 1.00 & 160.33 & 4.20 & 16 & 400 \\
\hline $\mathbf{3}$ & 40.67 & 1.66 & 1.33 & 168.67 & 5.03 & 20 & 390 \\
\hline $\mathbf{4}$ & 42.33 & 1.78 & 1.67 & 190.67 & 5.20 & 25 & 450 \\
\hline $\mathbf{5}$ & 38.67 & 2.17 & 1.33 & 176.67 & 5.30 & 22 & 460 \\
\hline $\mathbf{6}$ & 49.33 & 2.27 & 1.33 & 189.00 & 5.27 & 24 & 500 \\
\hline $\mathbf{7}$ & 48.00 & 2.00 & 1.33 & 197.67 & 5.17 & 25 & 600 \\
\hline $\mathbf{8}$ & 44.00 & 2.30 & 2.00 & 163.33 & 5.23 & 18 & 460 \\
\hline $\mathbf{9}$ & 43.67 & 2.50 & 2.00 & 178.33 & 5.00 & 19 & 460 \\
\hline $\mathbf{1 0}$ & 47.33 & 2.33 & 1.33 & 180.00 & 5.30 & 20 & 480 \\
\hline S. Em & 1.09 & 0.22 & 0.26 & 1.38 & 1.41 & 1.09 & 0.60 \\
\hline $\mathbf{C V}$ & 4.27 & 18.38 & 28.89 & 1.34 & 4.89 & 6.94 & 12.42 \\
\hline F Test & $*$ & $* *$ & $* *$ & $*$ & $*$ & $*$ & $*$ \\
\hline CD@ 5\% & 3.17 & 0.65 & 0.75 & 4.04 & 4.11 & 3.26 & 27.21 \\
\hline
\end{tabular}

Note: * Significant, ** Non-significant 
Table.2 The yield and plant growth performance of grafted bush pepper plants

\begin{tabular}{|c|c|c|c|c|c|c|c|}
\hline Treatments & $\begin{array}{c}\text { Plant } \\
\text { height } \\
\text { (cm) }\end{array}$ & $\begin{array}{l}\text { Plant } \\
\text { girth } \\
\text { (cm) }\end{array}$ & $\begin{array}{l}\text { Branch } \\
\text { girth } \\
\text { (cm) }\end{array}$ & $\begin{array}{l}\text { Leaf } \\
\text { area } \\
\left(\mathrm{cm}^{2}\right)\end{array}$ & $\begin{array}{c}\text { Canopy } \\
\text { (cm) }\end{array}$ & $\begin{array}{c}\text { No. of } \\
\text { vegetative } \\
\text { branch(No) }\end{array}$ & $\begin{array}{c}\text { Yield } \\
\text { intercrops } \\
\text { (gms) }\end{array}$ \\
\hline 1 & 41.17 & 1.99 & 1.67 & 195.00 & 3.40 & 16 & 460 \\
\hline 2 & 47.27 & 2.10 & 1.67 & 188.00 & 3.40 & 18 & 460 \\
\hline 3 & 46.33 & 2.10 & 1.00 & 197.00 & 4.13 & 19 & 420 \\
\hline 4 & 48.00 & 1.93 & 1.67 & 182.67 & 4.33 & 17 & 460 \\
\hline 5 & 50.67 & 1.87 & 1.33 & 196.33 & 4.68 & 15 & 450 \\
\hline 6 & 51.00 & 2.03 & 1.33 & 209.33 & 4.60 & 16 & 480 \\
\hline 7 & 49.67 & 2.07 & 1.00 & 190.00 & 4.90 & 18 & 490 \\
\hline 8 & 47.67 & 1.93 & 1.67 & 202.67 & 4.80 & 20 & 500 \\
\hline 9 & 49.00 & 1.93 & 1.00 & 204.33 & 3.73 & 16 & 480 \\
\hline 10 & 50.33 & 2.07 & 1.00 & 203.33 & 4.03 & 18 & 490 \\
\hline S. Em & 0.36 & 0.03 & 0.26 & 3.75 & 1.18 & 2.11 & 7.42 \\
\hline CV & 1.35 & 2.97 & 34.16 & 3.30 & 4.86 & 6.11 & 10.10 \\
\hline F Test & $*$ & $*$ & $* *$ & $*$ & $*$ & $*$ & $*$ \\
\hline CD@ 5\% & 1.06 & 0.10 & 0.77 & 3.75 & 3.44 & 6.22 & 21.42 \\
\hline
\end{tabular}

Note: * Significant, ** Non-significant

Table.3 The plant growth performance of grafted paniyur - 1 pepper plant produced from orthotropic branches

\begin{tabular}{|c|c|c|c|c|c|c|}
\hline Treatments & $\begin{array}{c}\text { Plant height } \\
\text { (cm) }\end{array}$ & $\begin{array}{c}\text { Plant } \\
\text { girth } \\
\text { (cm) }\end{array}$ & $\begin{array}{c}\text { Branch } \\
\text { girth } \\
\text { (cm) }\end{array}$ & $\begin{array}{c}\text { Leaf } \\
\text { area } \\
\left(\mathbf{c m}^{\mathbf{2}}\right)\end{array}$ & $\begin{array}{c}\text { Canopy } \\
(\mathbf{c m})\end{array}$ & $\begin{array}{c}\text { No. of } \\
\text { vegetative } \\
\text { branch(No) }\end{array}$ \\
\hline $\mathbf{1}$ & 158.33 & 1.67 & 1.00 & 81.33 & 8.00 & 06 \\
\hline $\mathbf{2}$ & 153.33 & 1.83 & 1.33 & 91.33 & 8.27 & 07 \\
\hline $\mathbf{3}$ & 157.33 & 1.93 & 1.00 & 89.67 & 8.60 & 06 \\
\hline $\mathbf{4}$ & 149.67 & 1.97 & 1.00 & 84.67 & 7.97 & 08 \\
\hline $\mathbf{5}$ & 152.67 & 1.87 & 1.33 & 91.00 & 7.93 & 08 \\
\hline $\mathbf{6}$ & 142.00 & 1.83 & 1.00 & 90.33 & 8.53 & 06 \\
\hline $\mathbf{7}$ & 145.00 & 2.03 & 1.00 & 92.33 & 8.50 & 08 \\
\hline $\mathbf{8}$ & 151.00 & 2.00 & 1.00 & 86.67 & 8.40 & 07 \\
\hline $\mathbf{9}$ & 151.67 & 1.93 & 1.00 & 95.33 & 7.83 & 08 \\
\hline $\mathbf{1 0}$ & 151.00 & 1.63 & 1.33 & 95.33 & 8.20 & 09 \\
\hline S. Em & 3.93 & 0.15 & 0.09 & 2.67 & 0.15 & 0.18 \\
\hline $\mathbf{C V}$ & 9.91 & 13.89 & 14.43 & 5.15 & 3.17 & 3.44 \\
\hline F Test & $*$ & $* *$ & $*$ & $*$ & $*$ & $*$ \\
\hline CD @ 5\% & 8.55 & 0.44 & 0.25 & 7.80 & 0.44 & 0.58 \\
\hline
\end{tabular}

Note: * Significant, ** Non-significant 
Table.4 The plant growth performance of rooted paniyur - 1 pepper plant produced from orthotropic branches

\begin{tabular}{|c|c|c|c|c|c|c|}
\hline Treatments & $\begin{array}{c}\text { Plant height } \\
(\mathbf{c m})\end{array}$ & $\begin{array}{c}\text { Plant girth } \\
(\mathbf{c m})\end{array}$ & $\begin{array}{c}\text { Branch } \\
(\mathbf{c m})\end{array}$ & $\begin{array}{c}\text { Leaf area } \\
\left(\mathbf{c m}^{\mathbf{2}}\right)\end{array}$ & $\begin{array}{c}\text { Canopy } \\
(\mathbf{c m})\end{array}$ & $\begin{array}{c}\text { No. of } \\
\text { vegetative } \\
\text { branch(No) }\end{array}$ \\
\hline $\mathbf{1}$ & 126.00 & 1.83 & 4.33 & 128.33 & 37.33 & 10 \\
\hline $\mathbf{2}$ & 140.00 & 1.57 & 4.33 & 143.33 & 37.00 & 09 \\
\hline $\mathbf{3}$ & 131.67 & 2.00 & 4.00 & 161.00 & 40.00 & 11 \\
\hline $\mathbf{4}$ & 205.00 & 1.80 & 5.33 & 161.33 & 34.67 & 09 \\
\hline $\mathbf{5}$ & 189.33 & 1.90 & 5.00 & 180.00 & 35.00 & 08 \\
\hline $\mathbf{6}$ & 200.00 & 1.87 & 6.67 & 136.67 & 36.67 & 07 \\
\hline $\mathbf{7}$ & 226.67 & 2.03 & 4.00 & 138.00 & 37.00 & 09 \\
\hline $\mathbf{8}$ & 175.00 & 1.97 & 4.67 & 167.67 & 39.33 & 10 \\
\hline $\mathbf{9}$ & 193.00 & 1.93 & 4.00 & 173.33 & 40.33 & 10 \\
\hline $\mathbf{1 0}$ & 182.67 & 2.00 & 7.67 & 176.67 & 40.67 & 12 \\
\hline S. Em & 4.62 & 0.09 & 0.52 & 11.88 & 1.69 & 0.22 \\
\hline $\mathbf{C V}$ & 4.52 & 8.33 & 17.84 & 13.14 & 7.73 & 3.86 \\
\hline F Test & $*$ & $* *$ & $*$ & $*$ & $* *$ & $* *$ \\
\hline CD@ 5\% & 13.48 & 0.27 & 1.51 & 34.68 & 4.93 & 0.62 \\
\hline
\end{tabular}

Note: * Significant, ** Non-significant

Table.5 Effect of propagation method on successful growth performance of pepper plants

\begin{tabular}{|l|l|l|l|l|l|l|l|}
\hline & \multicolumn{2}{|c|}{ Total propagated cutting } & \multicolumn{2}{c|}{ Successful plants } & \multicolumn{2}{c|}{ Successful } \\
\hline Branches & $\begin{array}{l}\text { Propagation } \\
\text { method }\end{array}$ & Experiment & Commercial & $\begin{array}{l}\text { Experiment } \\
(\text { No) }\end{array}$ & $\begin{array}{l}\text { Commercial } \\
(\text { No) }\end{array}$ & $\begin{array}{l}\text { Experiment } \\
(\%)\end{array}$ & $\begin{array}{l}\text { Commercial } \\
(\%)\end{array}$ \\
\hline \multirow{2}{*}{ Arthrotropic } & Rooted & 100 & 75000 & 64 & 4875 & 64 & 64.10 \\
\cline { 2 - 9 } & Grafted & 100 & 3000 & 86 & 2585 & 86 & 86.16 \\
\hline \multirow{2}{*}{ Plagiotropic } & Rooted & 100 & 3000 & 35 & 1056 & $35 \%$ & 35.20 \\
\cline { 2 - 9 } & Grafted & 100 & 3000 & $95 \%$ & 2868 & $95 \%$ & 95.26 \\
\hline
\end{tabular}

The propagation study of Paniyur-1 pepper showed successful percentage of rooted pepper plants $(64 \%)$ and grafted pepper plants $(86 \%)$ were produced in rooted and grafted pepper cutting of orthotropic vine. The propagation study of plagiotropic branch of paniyur-1 produced successful $(35 \%)$ rooted pepper plants and grafted pepper $(95 \%)$. More per cent were observed in grafting method compared to rooting method of propagation.
The growth performance and development of rooted plants of orthotropic vine cuttings and plagiotropic branches showed significantly higher compared to grafted plants after the propagation. The growth performance of all the pepper plants were better in cashew orchard and is a sustainable crops in the field of horticulture, which found to have more performance in yield under coastal zone of Karnataka. 


\section{References}

Atal, C. K, Banga, S. S. 1962. Photochemical studies on stem of P. longum. Indian J. Pharm., 24:105. Council of Agricultural Research, New Delhi, pp.152-155.

Gomez, K. A, Gomez, A. A. 1984. Statistical procedures for agricultural research. $2^{\text {nd }}$ ed. New York : John Wiley and Sons.

Khandekar, R.G, Haldankar, P.M, Pande, V. S, Joshi, G. D, Bagade, D. S, Malve, D. B, Bhagwat N. R, Gangwala, A. D, Jambhale, N. D, Ramana, K. V. 2004. Studies on rapid multiplication of black pepper ( Piper nigrum L.) on soil mound. Journal of spices and
Aromatic Crops, 13(1): 34-36.

Panse, V. S. and Sukhatme, P. V., 1985, Statistical Methods for Agricultural Workers. Indian Howard, R. A.1973. Notes on the piperaceae of lesser Antilles. J. Arnold Arb., (54): 377- 411.

Scott, I. M, Jensen, H. R, Philogene, B. J. R, Amason, J. T. 2008. A review of Piper spp. (Piperaceae) Phytochemistry, insecticidal activity and mode of action. Phytochem. Rev., (7): 65-75.

Sivaraman, K. 1987. Rapid multiplication of quality planting material in black pepper. Indian Cocoa Arecanut Spices J., (11):115-118.

\section{How to cite this article:}

Lakshmana, Mahesh Math and Sachin. U. S. 2020. Influence of Propagation Technique on Successful Graft and Growth Performance of Pepper Plants. Int.J.Curr.Microbiol.App.Sci. 9(03): 2774-2779. doi: https://doi.org/10.20546/ijcmas.2020.903.319 